\title{
Escherichia coli is not a suitable fecal indicator to assess water fecal contamination by otters
}

\author{
M. Oliveira ${ }^{*}$, D. Freire ${ }^{a}$ and N. M. Pedroso ${ }^{b, c}$ \\ ${ }^{a}$ Centre for Interdisciplinary Research in Animal Health - CIISA, Faculdade de Medicina Veterinária, \\ Universidade de Lisboa, Av. da Universidade Técnica, CEP 1300-477, Lisboa, Portugal

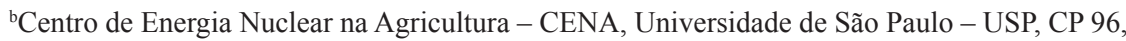 \\ CEP 13416-000, Piracicaba, SP, Brazil \\ ${ }^{\mathrm{c} C e n t r e ~ f o r ~ E c o l o g y, ~ E v o l u t i o n ~ a n d ~ E n v i r o n m e n t a l ~ C h a n g e ~-~ c E 3 c, ~ F a c u l d a d e ~ d e ~ C i e ̂ n c i a s, ~}$ \\ Universidade de Lisboa, Ed. C2, Campo Grande, 1749-016, Lisboa, Portugal \\ *e-mail: moliveira@fmv.ulisboa.pt
}

Received: July 29, 2016 - Accepted: September 21, 2016 - Distributed: February 28, 2018

(With 1 figure)

\begin{abstract}
The detection of pathogenic microorganisms in aquatic environments is extremely relevant in terms of public health. As these laboratorial methodologies are usually difficult, expensive and time-consuming, they are frequently replaced by the assessment of fecal indicator bacteria, such as Escherichia coli. This study aimed to assess the presence of $E$. coli in fecal samples from Neotropical otters, to evaluate its potential as fecal indicator to be applied to the determination of water microbiological quality in areas where otters' populations are high. Twenty-six otter fecal samples, collected in Alto Paranapanema river basin, São Paulo State, Brazil, were analyzed for the presence of E. coli, using conventional bacteriological methods. Only 8 scat samples $(30 \%)$ were $E$. coli positive, indicating that this microorganism is not a suitable fecal indicator to assess water fecal contamination by Neotropical otters, and should not be used to infer the presence of otter related pathogens in waters.
\end{abstract}

Keywords: Escherichia coli, fecal contamination, fecal indicator, Lontra longicaudis, Neotropical otter.

\section{Escherichia coli não é um indicador adequado para avaliar a contaminação fecal da água por lontras}

\section{Resumo}

A detecção de microrganismos patogênicos em ambientes aquáticos é extremamente importante em termos de saúde pública. Como estas metodologias laboratoriais são geralmente difíceis de realizar, dispendiosas e demoradas, são frequentemente substituídas pela avaliação de bactérias indicadoras de contaminação fecal, tais como Escherichia coli. Este estudo teve como objetivo avaliar a presença de E. coli em amostras fecais de lontras Neotropicais, para avaliar o seu potencial como indicador fecal e poder ser aplicado para a determinação da qualidade microbiológica da água em áreas onde as populações de lontras são numerosas. Vinte e seis amostras de fezes de lontra, coletadas na bacia do Alto Paranapanema, Estado de São Paulo, Brasil, foram analisadas quanto à presença de E. coli, utilizando métodos bacteriológicos convencionais. Apenas oito amostras de fezes (30\%) se revelaram positivas para E. coli, indicando que este microrganismo não é um indicador fecal adequado para avaliar a contaminação fecal da água por lontras Neotropicais, e não deve ser usada para inferir a presença de agentes patogênicos relacionados com lontra em águas.

Palavras-chave: Escherichia coli, contaminação fecal, indicador fecal, Lontra longicaudis, lontra Neotropical.

\section{Introduction}

The detection of pathogenic microorganisms in aquatic environments is extremely relevant in terms of public health (Ahmed et al., 2015). Since their laboratorial detection by culture-based methods, as recommended by international guidelines, is difficult, expensive and time-consuming, the direct detection of pathogenic microorganisms is frequently replaced by the assessment of fecal indicator bacteria, such as Escherichia coli (Schriewer et al., 2010; Ahmed et al., 2015). This fecal indicator bacterial species can be related with the microbiological quality of waters (McFeters et al., 1974), since it is a commensal bacteria present in the gastrointestinal tract of warm-blooded animals, including humans (Schriewer et al., 2010; Ahmed et al., 2015). In fact, it has long been considered as 
the best indicator for the presence of Salmonella, a known pathogenic bacterial genus, frequently disseminated in the environment through fecal contamination (McFeters et al., 1974; Truchado et al., 2016).

Although otters can be affected by several types of infectious diseases (Simpson, 2000), valid information about the clinical significance of Neotropical otter (Lontra longicaudis Olfers, 1818) fecal isolates and their relevance in terms of environmental contamination hasn't been assessed. Such studies would be extremely important, since it has been previously demonstrated that other otter species, namely Eurasian otters (Lutra lutra Linnaeus, 1758), can be potential carriers of pathogenic and antimicrobial resistant bacteria, including Salmonella (Oliveira et al., 2010a; Semedo-Lemsaddek et al., 2013).

Although E. coli is a good fecal indicator, it has not yet been fully proven as suitable to assess water fecal contamination by otters. In a previous study conducted by our research team (Oliveira et al., 2008), 31 otter fecal samples collected in Sado river basin, Alentejo province, south of Portugal, were analyzed, being possible to obtain 132 bacterial isolates, from which only 3 (2.3\%) were identified as members of the genera Escherichia. Therefore, it is necessary to first confirm the presence of adequate concentrations of $E$. coli in the gastrointestinal tract of other otters' species, before considering its potential as a good indicator for assessing water fecal contamination by these carnivores in various climatic zones.

The Neotropical otter is a predator (Carnivora, Mustelidae) that can be found in Central and South America, with a distribution ranging from Mexico to Argentina (Rheingantz and Trinca, 2015). It is present in a wide range of aquatic environments, like rocky shores, coastal wetlands, tropical, humid and deciduous forests, being found from sea level up to $4,000 \mathrm{~m}$ altitude, in a wide variety of water bodies (e.g. rivers, lakes, marshes, reservoirs) (Eisenberg and Redford, 1999; Rheingantz and Trinca,
2015). Recently its conservation status was upgraded from "Data Deficient" to "Near Threatened" by the IUCN. The recent increase in the information available about the species allowed this status change, due to the probability of local extinction. Although critical data on aspects of the Neotropical otter biology, demography and behavior, along with interaction with man, are still lacking for many areas, the effects of a large variety of anthropogenic threats such as pollution, gold mining, habitat loss, while not rigorously estimated, are likely to be increasing (Barbieri et al., 2012; Rheingantz and Trinca, 2015). The threats for the species include, among others, contamination and pollution of aquatic environments (e.g. González and Utrera, 2004; IBAMA, 2001). However, while sensitive to chemical and organic pollution, the species is also present in areas with high level of human influence such as agricultural and activities and sewage flowing into the river (Pardini and Trajano, 1999; Rheingantz et al., 2011). It is not known if their present near human populations represents a risk for the dissemination of zoonotic bacteria like Salmonella, since, as previously referred, there are no studies available on bacterial infectious diseases in L. longicaudis or on their importance regarding bacterial environmental contamination.

This study aimed to assess the presence of $E$. coli in fecal samples from Neotropical otters, in order to evaluate the potential of this bacterial species as fecal indicator to be applied to the determination of water microbiological quality in areas where otter's populations are high.

\section{Materials and Methods}

\subsection{Study area}

The study was carried out along a 13-km stretch of the Paranapanema River, situated in the Campina do Monte Alegre and Paranapanema municipalities, in São Paulo State, Brazil (2329.1004' S, 48 $37.5447^{\prime}$ W; Figure 1). This stretch of river that starts at "Bairro da Ponte", a

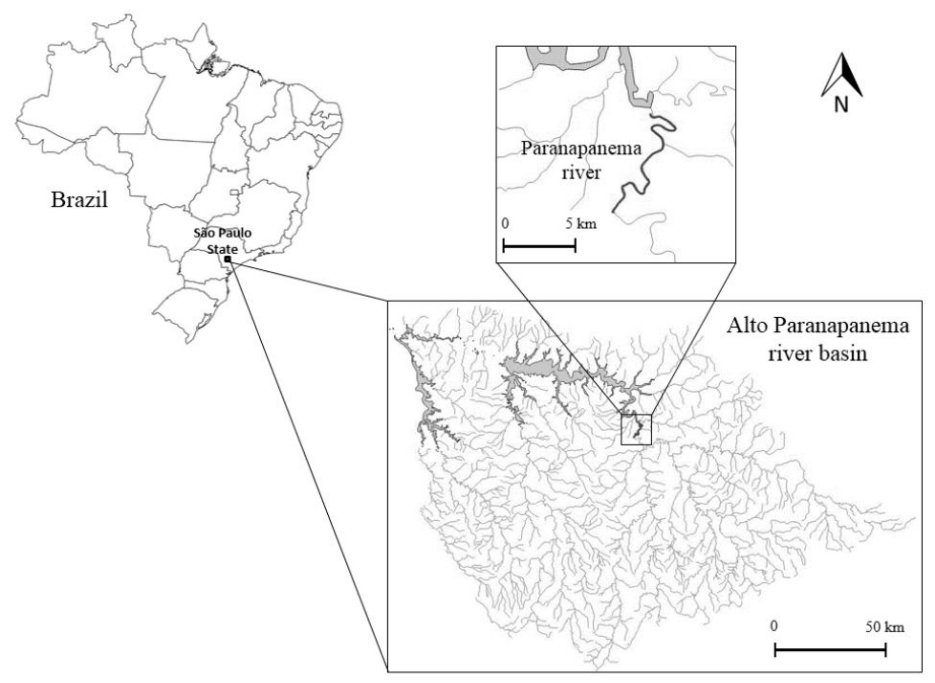

Figure 1. Study area location within Alto Paranapanema river basin, São Paulo State, Brazil. 
small fishing village, is located upstream of the Jurimirim hydroelectric station, with bordering landscape composed of riverine forests (with varying disturbance levels) and agro-silvo-pastoral fields (e.g. Eucalyptus, corn and cotton plantations, cattle breeding pastures) (IBGE, 2016). The area is characterized by a sub-tropical climate, namely Cwa type according to Köppen climate classification (Peel et al., 2007), with average temperatures of $22^{\circ} \mathrm{C}$ in the warmest month (March) and $17^{\circ} \mathrm{C}$ in the coldest (June).

\subsection{Sample collection}

The study area was surveyed by boat in October and December 2015 and in April 2016 along the selected river stretch. Neotropical otter scats (feces), easily recognized by their specific characteristics (shape, smell and content), were collected along the river banks, near known otter dens and burrows. Several surveys were made during the early morning to ensure the sampling of fresh scats.

For each scat sample selected ( $\mathrm{n}=26)$, an AMIES swab (VWR, Portugal) was immediately performed for bacteria isolation and identification, being kept refrigerated until further processing at the Laboratory of Microbiology and Immunology, Faculty of Veterinary Medicine, University of Lisbon, Portugal.

\subsection{Bacterial detection by conventional culture method}

Bacterial isolation and quantification in otter fecal samples was performed using conventional bacteriological methods, namely inoculation onto Tryptone Bile X-glucuronide agar (TBX) (BioKar Diagnostics, Beauvais, France) (Oliveira et al., 2016). Plates were incubated at $37^{\circ} \mathrm{C}$ for $24 \mathrm{~h}$. Isolates were characterized through their macro-and microscopic morphology, staining, and biochemical characteristics (catalase and oxidase reactions).

\section{Results}

All gram-negative bacilli, catalase-positive and oxidase-negative, that originated blue colonies in TBX agar were presumptively identified as E. coli. Eight samples (30\%) were E. coli positive.

\section{Discussion}

In recent years, there has been a growing concern regarding the bacterial diseases that affect tropical wild animals, considering their zoonotic and environmental contamination potential. This is especially important for animals inhabiting aquatic environments, such as the Neotropical otter, since water can be an important reservoir of pathogenic bacteria responsible for infections in other animals, including humans (Ahmed et al., 2015). In the particular case of this otter species, no work regarding these aspects is being conducted, in spite of previous reports referring that other otter species (e.g. Eurasian otter) can be affected by several types of infectious diseases (Simpson, 2000), and be potential carriers of pathogenic resistant bacteria (Oliveira et al., 2010b; Semedo-Lemsaddek et al., 2013).
As direct pathogen detection is difficult, indicator bacteria from fecal origins are used to evaluate the microbiology quality of aquatic environments, particularly regarding waters used by humans for consumption or recreational activities (Ervin et al., 2014; Schriewer et al., 2010). Indicator bacteria can be related with the presence of pathogens responsible for numerous serious diseases (Ervin et al., 2014; Schriewer et al., 2010; Truchado et al., 2016), which may have several animal origins, including humans, farm and domestic animals and wildlife. Although fecal contamination by humans represents a higher risk in terms of public health, the importance of contamination by other animals, including otters, should not be neglected, as they may also be carriers of relevant virulent microorganisms (Krentz et al., 2013; Ervin et al., 2014). In fact, Schriewer et al. (2010) pointed out the significant contribution of wild animals to the fecal contamination of aquatic environments.

This study aimed to evaluate the presence of Escherichia coli in Lontra longicaudis fecal samples, to evaluate the potential of this widely used indicator bacteria to assess fecal contamination of aquatic environments by these carnivores, independently of the location of their habitat, as climatic variations may influence the presence and concentration of fecal indicators in water samples (Ahmed et al., 2015).

Samples were collected at sites with regular Neotropical otter presence (Tavares et al., in press). Bacteria isolation and identification were performed according to established conventional microbiological procedures, already proved as suitable for the detection of environmental susceptible Gram-negative bacteria, such as E. coli, even when samples have to be transported between long distances (Oliveira et al., 2010a).

However, only less than one third of the otter scat samples were found to be positive for E. coli. These results are in accordance with previous studies performed using samples from other otter species collected at distinct climatic zones that also describe a low occurrence of this bacterial species in otter scats (Oliveira et al., 2008; Miller et al., 2010). They also support other reports that criticize the suitability of E. coli as a good indicator bacterial species, which mainly question the correlation between the presence of $E$. coli and of relevant pathogenic microorganisms in aquatic environments (Schriewer et al., 2010; Ahmed et al., 2015).

As otters can carry potential pathogenic bacteria (Simpson, 2000; Oliveira et al., 2008, 2010b; Miller et al., 2010), the evaluation of otter fecal microorganisms in aquatic environments would be extremely relevant for public health, allowing to establish proper management and monitoring plans to avoid serious risks to human health. Therefore, Escherichia coli is not a suitable fecal indicator to assess water fecal contamination by Neotropical otters, and should not be used to infer the presence of otter related pathogens in waters. Further research must be conducted in order to determine which is the best bacterial group to be considered as a good fecal indicator. 


\section{Acknowledgements}

We would like to thank Sofia V. Dias and Luciano M. Verdade for the help in the field work. NMP was supported by grant \#2014/08601-6, São Paulo Research Foundation (FAPESP).

\section{References}

AHMED, W., SIDHU, J.P.S., SMITH, K., BEALE, D., GYAWALI, P. and TOZE, S., 2015. Distributions of fecal markers in wastewater from different climatic zones for human fecal pollution tracking in Australian surface waters. Applied and Environmental Microbiology, vol. 82, no. 4, pp. 1316-1323. PMid:26682850. http://dx.doi.org/10.1128/AEM.03765-15.

BARBIERI, F., MACHADO, R., ZAPPES, C.A. and OLIVEIRA, L.R., 2012. Interactions between the Neotropical otter (Lontra longicaudis) and gillnet fishery in the southern Brazilian coast. Ocean and Coastal Management, vol. 63, pp. 16-23. http://dx.doi. org/10.1016/j.ocecoaman.2012.03.007.

EISENBERG, J.F. and REDFORD, K.H.,1999. Mammals of the Neotropics: the Central Neotropics - Ecuador, Bolivia, Brazil. Chicago: University of Chicago Press. 624 p. Mammals of the Neotropics, no. 3 .

ERVIN, J.S., VAN DE WERFHORST, L.C., MURRAY, J.L. and HOLDEN, P.A., 2014. Microbial source tracking in a coastal California watershed reveals canines as controllable sources of fecal contamination. Environmental Science \& Technology, vol. 48, no. 16, pp. 9043-9052. PMid:25055204. http://dx.doi. org/10.1021/es502173s

GONZÁLEZ, I. and UTRERA, A., 2004. Distribution of the Neotropical Otter Lontra longicaudis in the Venezuelan Andes: Habitat and Status of its Population. IUCN Otter Specialist Group Bulletin, vol. 21, no. 2, pp. 86-92.

INSTITUTO BRASILEIRO DE GEOGRAFIA E ESTATÍSTICA - IBGE, 2016 [viewed 12 June 2016]. Geociências. IBGE [online]. Available from: http://downloads.ibge.gov.br/downloads geociencias.htm\#

INSTITUTO BRASILEIRO DO MEIO AMBIENTE E DOS RECURSOS NATURAIS RENOVÁVEIS - IBAMA, 2001. Mamíferos aquáticos do Brasil: plano de ação. 2nd ed. Brasília: Ministério do Meio Ambiente. 61 p. Série Estudos Educação Ambiental, no. 2.

KRENTZ, C.A., PRYSTAJECKY, N. and ISAAC-RENTON, J., 2013. Identification of fecal contamination sources in water using host-associated markers. Canadian Journal of Microbiology, vol. 59, no. 3, pp. 210-220. PMid:23540340. http://dx.doi.org/10.1139/ cjm-2012-0618.

MCFETERS, G.A., BISSONNETTE, G.K., JEZESKI, J.J., THOMSON, C.A. and STUART, D.G., 1974. Comparative survival of indicator bacteria and enteric pathogens in well water. Applied Microbiology, vol. 27, no. 5, pp. 823-829. PMid:4598219.

MILLER, M.A., BYRNE, B.A., JANG, S.S., DODD, E.M., DORFMEIER, E., HARRIS, M.D., AMES, J., PARADIES, D., WORCESTER, K., JESSUP, D.A. and MILLER, W.A., 2010. Enteric bacterial pathogen detection in southern sea otters (Enhydra lutris nereis) is associated with coastal urbanization and freshwater runoff. Veterinary Research, vol. 41, no. 1, pp. 1-13. PMid:19720009. http://dx.doi.org/10.1051/vetres/2009049.
OLIVEIRA, M., MONTEIRO, J.L., RANA, S. and VILELA, C.L., 2010a. Antimicrobial resistance in Gram-positive bacteria from Timorese River Buffalo (Bubalus bubalis) skin microbiota. Tropical Animal Health and Production, vol. 42, no. 5, pp. 833-839. PMid:19898998. http://dx.doi.org/10.1007/s11250-009-9494-5.

OLIVEIRA, M., PEDROSO, N.M., SALES-LUÍS, T., SANTOSREIS, M., TAVARES, L. and VILELA, C.L., 2010b. Antimicrobialresistant Salmonella isolated from Eurasian otters (Lutra lutra Linnaeus, 1758) in Portugal. Journal of Wildlife Diseases, vol. 46, no. 4, pp. 1257-1261. PMid:20966276. http://dx.doi. org/10.7589/0090-3558-46.4.1257.

OLIVEIRA, M., SALES-LUÍS, T., DUARTE, A., NUNES, S.F., CARNEIRO, C., TENREIRO, T., TENREIRO, R., SANTOS-REIS, M., TAVARES, L. and VILELA, C.L., 2008. First assessment of microbial diversity in faecal microflora of Eurasian otter (Lutra lutra Linnaeus, 1758) in Portugal. European Journal of Wildlife Research, vol. 54, no. 2, pp. 245-252. http://dx.doi.org/10.1007/ s10344-007-0137-8.

OLIVEIRA, M., SERRANO, I., VAN-HARTEN, S., BESSA, L.J., BERNARDO, F. and COSTA, P.M., 2016. Fecal contamination of wastewater treatment plants in Portugal. Environmental Science and Pollution Research International, vol. 23, no. 14, pp. 14671-14675. PMid:27236442. http://dx.doi.org/10.1007/ s11356-016-6962-0

PARDINI, R. and TRAJANO, E., 1999. Use of shelters by the Neotropical river otter (Lontra longicaudis) in an Atlantic forest stream, Southeastern Brazil. Journal of Mammalogy, vol. 80, no. 2, pp. 600-610. http://dx.doi.org/10.2307/1383304.

PEEL, M.C., FINLAYSON, B.L. and MCMAHON, T.A., 2007. Updated world map of the Köppen-Geiger climate classification. Hydrology and Earth System Sciences, vol. 11, no. 5, pp. 16331644. http://dx.doi.org/10.5194/hess-11-1633-2007.

RHEINGANTZ, M.L. and TRINCA, C.S., 2015 [viewed 12 June 2016]. The IUCN red list of threatened species: Lontra longicaudis. [online]. Available from: http://dx.doi.org/10.2305/ IUCN.UK.2015-2.RLTS.T12304A21937379.en

RHEINGANTZ, M.L., WALDEMARIN, H.F., RODRIGUES, L. and MOULTON, T.P., 2011. Seasonal and spatial differences in feeding habits of the Neotropical otter Lontra longicaudis (Carnivora: Mustelidae) in a coastal catchment of southeastern Brazil. Zoologia, vol. 28, no. 1, pp. 37-44. http://dx.doi.org/ 10.1590/S1984-46702011000100006.

SCHRIEWER, A., MILLER, W.A., BYRNE, B.A., MILLER, M.A., OATES, S., CONRAD, P.A., HARDIN, D., YANG, H.H., CHOUICHA, N., MELLI, A., JESSUP, D., DOMINIK, C. and WUERTZ, S., 2010. Presence of Bacteroidales as a predictor of pathogens in surface waters of the central California coast. Applied and Environmental Microbiology, vol. 76, no. 17, pp. 5802-5814. PMid:20639358. http://dx.doi.org/10.1128/AEM.00635-10.

SEMEDO-LEMSADDEK, T., NÓBREGA, C.S., RIBEIRO, T., PEDROSO, N.M., SALES-LUÍS, T., LEMSADDEK, A., TENREIRO, R., TAVARES, L., VILELA, C.L. and OLIVEIRA, M., 2013. Virulence traits and antibiotic resistance among enterococci isolated from Eurasian otter (Lutra lutra). Veterinary Microbiology, vol. 163, no. 3-4, pp. 378-382. PMid:23375652. http://dx.doi.org/10.1016/j.vetmic.2012.12.032.

SIMPSON, V.R., 2000. Veterinary advances in the investigation of wildlife diseases in Britain. Research in Veterinary Science, vol. 69, no. 1, pp. 11-16. PMid:10924388. http://dx.doi.org/10.1053/ rvsc. 2000.0384 . 
TAVARES, J.L., LACORTE, M.C., PEDROSO, N.M., ROSALINO, L.M. and VERDADE, L.M., (In press). Neotropical otters in humanaltered environments: diet, dens and fishermen perceptions. In: E.D.L. SAN, J.J. SATO, J.L. BELANT and M.J. SOMERS, eds. Small carnivores: evolution, ecology, behaviour and conservation. Oxford: Wiley-Blackwell.
TRUCHADO, P., LOPEZ-GALVEZ, F., GIL, M.I., PEDREROSALCEDO, F., ALARCÓN, J.J. and ALLENDE, A., 2016. Suitability of different Escherichia coli enumeration techniques to assess the microbial quality of different irrigation water sources. Food Microbiology, vol. 58, pp. 29-35. PMid:27217356. http:// dx.doi.org/10.1016/j.fm.2016.03.006. 